\title{
Pilihan Karir Mahasiswa Preklinik dan Lulusan Kedokteran YARSI
}

\section{Career Preferences Among Preclinical and Graduated of YARSI Medical Students}

\author{
Zwasta Pribadi Mahardhika, Miranti Pusparini \\ Medical Education Centre, Faculty of Medicine, YARSI University, Jakarta \\ Koresponden E-Mail: zwasta.pribadi@yarsi.ac.id
}

\begin{abstract}
Abstrak
Motivasi seorang dokter dalam memilih karir telah banyak diteliti. Pilihan jalur karir dapat dipengaruhi oleh pengalaman pada pendidikan klinik. Tujuan penelitian ini adalah membandingkan pilihan karir antara mahasiswa preklinik dan lulusan kedokteran YARSI. Survei dilakukan pada 152 mahasiswa preklinik dan 88 lulusan mahasiswa kedokteran YARSI selaman Desember 2017. Data dikumpulkan menggunakan kuesioner yang diisi sendiri dan dianalisa dengan chi-square. Hasil menunjukkan tidak ada perbedaan karekteristik antara mahasiswa preklinik dan lulusan kecuali asal daerah. Penelitian menunjukkan bahwa mayoritas (69\%) responden berencana langsung bekerja setelah internship dan akan melanjutkan pendidikan spesialis (83\%). Alasan utama (61\%) memilih untuk bekerja adalah mencari pengalaman. Mayoritas responden memilih bekerja di rumah sakit dan Jakarta merupakan area pilihan untuk berpraktik. Mereka juga lebih memilih menjadi seorang klinisi. Bagi responden yang memilih langsung melanjutkan studi, spesialisasi merupakan pilihan utama (83\%). Tidak terdapat perbedaan pilihan karir antara mahasiswa preklinik dan lulusan kedokteran kecuali sektor pekerjaan $(p<0.001)$. Tidak ada perbedaan pilihan karir antara mahasiswa preklinik dengan lulusan kedokteran yang telah melewati pendidikan klinik.
\end{abstract}

Kata Kunci: Pilihan karir, mahasiswa preklinik, lulusan, spesialisasi

\begin{abstract}
Motivation of a medical doctor in the career preference has been developed during study. The choices of career path might be influenced by experiences in clinical education. The aim of this study was to compare career preferences between pre-clinical and graduated YARSI medical students: $A$ survey was conducted on 152 preclinical and 88 pre-graduated YARSI medical students during December 2017. Data were collected by using self-administered questionnaire and analyzed by chisquare. The results showed that preclinical and graduated students have no differences background except location of their origin. The results showed that the majority (69\%) of respondents planned to work immediately after internship, and would continue to further specialization education (83\%). The main reason (61\%) of choose work was having experienced. The majority of respondents would work at hospital and Jakarta was the favorite location to practice. Being clinician was most preferable
\end{abstract}


(95\%). Furthermore, respondents who plan to directly continue their education immediately after graduated would choose specialization education (83\%). There was no career preference difference between preclinical and graduated medical students except career sector $(p<0.001)$. Conclusion of this research was no difference career preferences between preclinical and graduated students although graduated students has trough clinical education.

Keywords:career choice, pre-clinical students, graduated students, specialization.

\section{Introduction}

In term of the ratio of the need for medical personnel to the total population in Indonesia for general practitioners and specialists based on the Health Care Development Plan of 2011-2025 is appropriate. The ratio of general practitioners is set at 40 doctors per 100,000 population while the ratio of specialists is 10 doctors per 100,000 population. The ratio of physicians in Indonesia in 2014 amounted to 16.18 GPs per 100,000 population and 18.04 specialists per 100,000 population. However, the needs of doctors, especially specialists by type and distribution is not evenly distributed (Ministry of Health RI, 2015).

Faculty of medicine as an educational institution that produces doctors play a role in meeting the needs of doctors for the community. Since April 2016, the number of medical faculties has increased to 75 medical faculties throughout Indonesia (Brodjonegoro, 2016). Based on these facts, it is possible that there will be excess in terms of quantity and deprivation in terms of type and distribution. Therefore the faculty of medicine has a role in providing direction to students to choose their future career.

The types of work and further education for medical school graduates vary greatly. They can continue as clinical doctors as well as nonclinicians but still use their medical scholarship such as researchers and academics. Further education of a physician is not limited to specialist medical education but also available in master's education. The education of specialist doctors are now very diverse. Nevertheless, medical students still have difficulty in conducting the selection of work or further education that will be followed (Gondodiputro, 2009).

Many factors influence a medical student in planning their future career choices. These factors include student characteristics, family, environment, and experience (Ferdian, 2015). Motivation of a medical doctor in the career preference has been developed during study. The choices of career path might be influenced by experiences in clinical education (Newton, 2005). The aim of this study was to compare career preferences between pre-clinical and graduated YARSI medical students.

\section{Methods}

A survey was conducted on 152 preclinical and 88 pre-graduated YARSI medical students during December 2017. The instrument used in this study was a questionnaire consisting of three parts, namely: demographic characteristics, students' career preferences, and factors that affect career choice. Demographic characteristics include gender, age, area of origin, parents' job and choice to 
entry medical school. Career preferences includes: plan after internship, work sector, preferred profession, preferred setting of practice, preferred area of practice, choice of further study, choice of specialty, and factors than influenced their choice doctors. Chi-square calculated to compare between pre-clinical and pre-graduated students in variable of career preferences.

\section{Results}

The majority of students both pre-clinical students (74\%) and pre-graduated students (61\%) chose to work first rather than directly to continue the study. However, there were students who do not have plans after completion of internship. Their main reason for the work ahead was to get experiences. The most preferred jobs sector varies between pre-clinical students and pre-graduated students ( $p<0.001)$.
Pre-clinical students preferred to work in private sector while pre-graduated students preferred to work in public sector. Being a clinician is preferred by the majority of students over others. The first setting of preference was hospital with prvate practice second and clinic setting third. Jakarta has become the preferred work area followed by the surrounding area. Continuing specialist education was a major career choice compared to continuing master's education. However, some students have not decided yet to continue their study options.

If the student was asked to name three options of his specialty then the top five options are obstetrician, pediatrician, dermatologist, internist, and neurologist for pre-clinical student. While pre-graduated students chose dermatologist, obstetrician, neurologist, ophthalmologist and cardiologist as the top five choices (figure 1 and 2).

Table 1. Demographic Characteristics

\begin{tabular}{|c|c|c|c|c|}
\hline \multicolumn{2}{|c|}{ Variable } & \multirow{2}{*}{$\begin{array}{c}\begin{array}{c}\text { Preclinical students } \\
\text { (N=152) }\end{array} \\
30(20)\end{array}$} & \multirow{2}{*}{$\begin{array}{c}\begin{array}{c}\text { Pregraduated } \\
\text { students }(\mathbf{N}=\mathbf{8 8})\end{array} \\
19(22)\end{array}$} & \multirow{2}{*}{$\frac{\mathbf{p}}{0.731}$} \\
\hline Gender & Male n(\%) & & & \\
\hline & Female $\mathrm{n}(\%)$ & $122(80)$ & $69(78)$ & \\
\hline Age & Mean & 21.87 & 23.83 & \\
\hline \multirow[t]{4}{*}{ Origin } & Jakarta & $49(32)$ & 28(32) & 0.02 \\
\hline & Bodetabek & $34(22)$ & $25(28)$ & \\
\hline & Capital of province & $38(25)$ & $6(9)$ & \\
\hline & Others & $31(21)$ & $29(33)$ & \\
\hline \multirow[t]{4}{*}{ Parents' Job } & Doctor & $21(14)$ & $9(10)$ & 0.701 \\
\hline & $\begin{array}{l}\text { Health care } \\
\text { provider }\end{array}$ & $12(8)$ & $8(9)$ & \\
\hline & Others & $119(78)$ & $71(81)$ & \\
\hline & Self & $63(41)$ & $43(49)$ & 0.08 \\
\hline \multirow{2}{*}{$\begin{array}{l}\text { Choice entry } \\
\text { medical school }\end{array}$} & Parent & $24(16)$ & $11(12)$ & \\
\hline & Both & $65(43)$ & $34(39)$ & \\
\hline
\end{tabular}


Table 2. Career Preferences after Graduated from Medical School

\begin{tabular}{|c|c|c|c|c|}
\hline & Variable & $\begin{array}{l}\text { Pre-clinical } \\
\text { Students }\end{array}$ & $\begin{array}{c}\text { Pre- } \\
\text { graduated } \\
\text { students }\end{array}$ & $\mathbf{p}$ \\
\hline \multirow{4}{*}{$\begin{array}{l}\text { Plan after } \\
\text { internship }\end{array}$} & Work n(\%) & $113(74)$ & $54(61)$ & 0.088 \\
\hline & Continuing to study $n(\%)$ & $37(25)$ & $31(35)$ & \\
\hline & Not yet decided n(\%) & $2(1)$ & $3(4)$ & \\
\hline & Total & 152 & 88 & \\
\hline \multicolumn{5}{|c|}{ for those who choose to work } \\
\hline \multirow{4}{*}{$\begin{array}{l}\text { Reason of } \\
\text { choose to work }\end{array}$} & Experience $\mathrm{n}(\%)$ & $70(62)$ & $32(59)$ & 0.917 \\
\hline & Saving n(\%) & $26(23)$ & $14(26)$ & \\
\hline & Others $\mathrm{n}(\%)$ & $17(15)$ & $8(15)$ & \\
\hline & Total & 113 & 54 & \\
\hline \multirow[t]{4}{*}{ Work sector } & Public n(\%) & $23(20)$ & $25(46)$ & 0.001 \\
\hline & Private $\mathrm{n}(\%)$ & $33(29)$ & $15(28)$ & \\
\hline & Not yet decided n(\%) & $57(51)$ & $14(26)$ & \\
\hline & Total & 113 & 54 & \\
\hline \multirow{3}{*}{$\begin{array}{l}\text { Preferred } \\
\text { profession }\end{array}$} & Clinician n(\%) & 109(96) & $50(93)$ & 0.274 \\
\hline & Non Clinician n(\%) & $4(4)$ & $4(7)$ & \\
\hline & Total & 113 & 54 & \\
\hline \multirow{4}{*}{$\begin{array}{l}\text { Preferred } \\
\text { settings for } \\
\text { practice }\end{array}$} & Private & 52 & 45 & NA \\
\hline & Clinic & 39 & 31 & \\
\hline & Puskesmas & 25 & 17 & \\
\hline & Hospital & 83 & 47 & \\
\hline \multirow{5}{*}{$\begin{array}{l}\text { Preferred area } \\
\text { for practice }\end{array}$} & Jakarta n(\%) & $37(34)$ & $15(30)$ & 0.479 \\
\hline & Bodetabek n(\%) & $22(20)$ & $13(26)$ & \\
\hline & Capital of Province $n(\%)$ & $29(27)$ & $9(18)$ & \\
\hline & Others $\mathrm{n}(\%)$ & $21(19)$ & $13(26)$ & \\
\hline & Total & 109 & 50 & \\
\hline \multirow{5}{*}{$\begin{array}{l}\text { Preferred career } \\
\text { after work }\end{array}$} & Specialist n(\%) & $95(84)$ & $44(81)$ & 0.214 \\
\hline & Master $\mathrm{n}(\%)$ & $5(4)$ & $3(6)$ & \\
\hline & General practitioner $n(\%)$ & $0(0)$ & $2(5)$ & \\
\hline & Not yet decided n(\%) & $13(12)$ & $5(8)$ & \\
\hline & Total & 113 & 54 & \\
\hline \multicolumn{5}{|c|}{ For those who choose directly go to study } \\
\hline \multirow{4}{*}{$\begin{array}{l}\text { choice of further } \\
\text { study }\end{array}$} & Specialist n(\%) & $33(89)$ & $24(78)$ & 0.385 \\
\hline & Master $\mathrm{n}(\%)$ & $3(8)$ & $6(19)$ & \\
\hline & Not yet decided n(\%) & $1(3)$ & $1(3)$ & \\
\hline & Total & 37 & 31 & \\
\hline
\end{tabular}






Figure 1. Pre-clinical students' specialty choices $(n=128)$

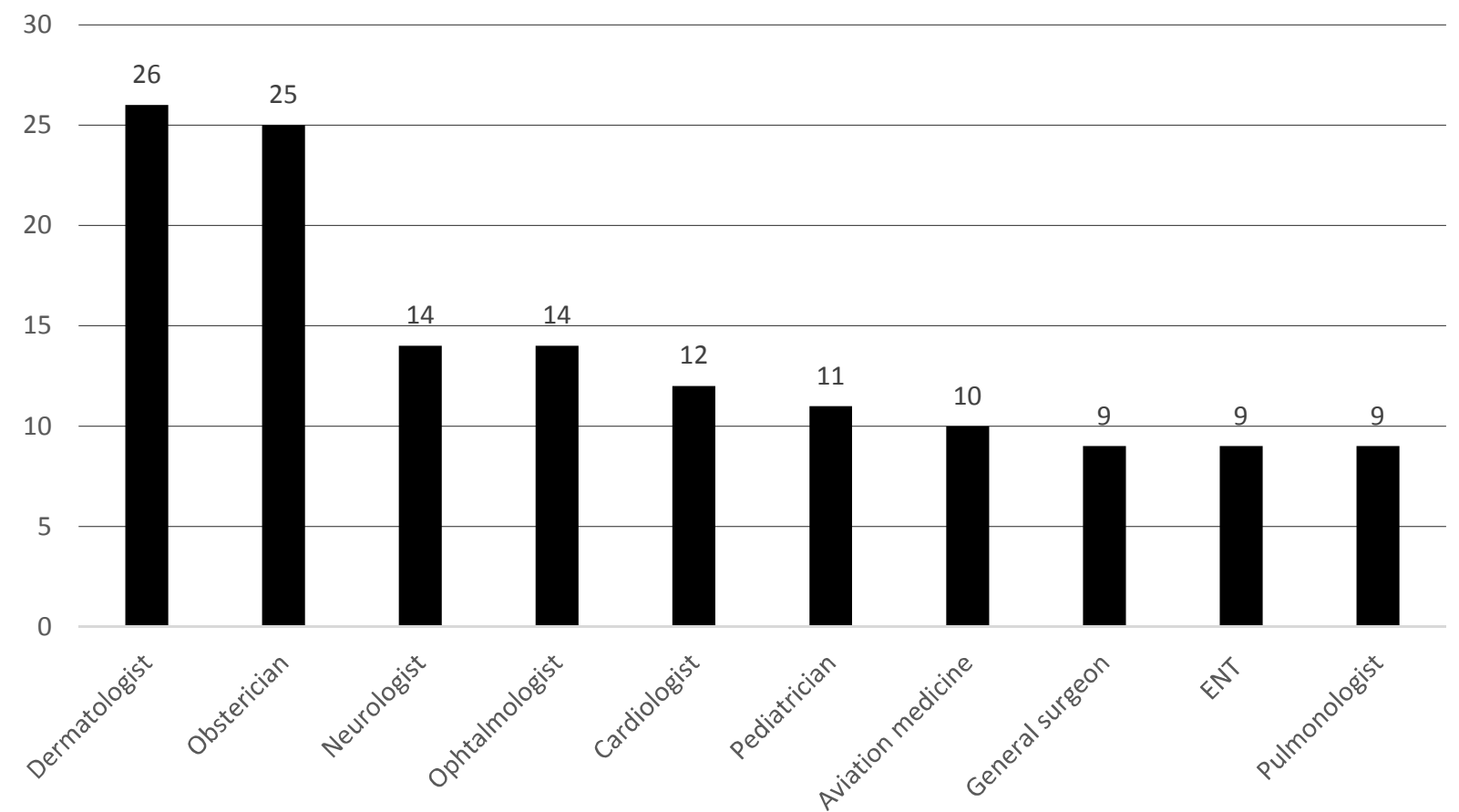

Figure 2. Pre-graduated students' specialty choices $(n=68)$ 


\section{Discussion}

Medical students after graduation can choose to work or directly continue education either academic nature that is education magister or education that is profession that is specialist education. For those who work, more doctor graduates choose to become clinicians than as teachers or researchers (She, 2008). The choice to become a specialist is more than the student who wants to be a general practicing physician (Lefevre, 2010).

Doctor who is in master's degree can take education which is still in one health area such as master of public health, master of medicine, master of health and safety, master of health law, master biomedical, master of science, master of epidemiology, master of hospital administration, magister of sports or master's health in the field of non-health (Gondodiputro, 2009).

Medical students in Indonesia generally plan to work first after graduation and then take further education. Specialist education most in demand by medical students is an internal medicine specialist, surgical specialist, pediatrician, and obstetrics and gynecology specialist. While the most popular master's education is master of hospital administration, master of public health, master of health law, and master of health economics (Gondodiputro, 2009). The choice is not much different from the students' choice in Sudan (Alawad, 2014), Pakistan (Huda, 2006), Kenya (Mwachaka, 2010), Nepal (Hayes, 2013) and Australia (Boyle, 2014) for specialization options.

Factors influencing the decision in choosing a career vary from individual characteristics, benefits that may be accepted, interest in specialization to factors related to the curriculum of the medical faculty. Student demographic factors such as gender have also clearly influenced the doctor's career choices. Male students prefer more surgical specialists than female students. They prefer specialists in internal medicine, child specialists and obstetrics and gynecology specialists (Fukuda, 2010; Khader, 2008; Huda, 2007; Mwachaka, 2010; and Boyle 2014). Motivation to become a doctor before entering medical faculty plays a role in determining career choices in the future (Hayes, 2013 and Syakurah, 2014). Khader (2008) argues that intellectual content of specialization and competence are the main factors affecting the choice of specialization apart from reputation and likely revenue, as well as handling that focuses on acute handling in a particular area of specialization. Based on research Lefevre (2010) found that the main motivation factor of a medical student choosing a particular specialization is an interest in certain diseases, opportunities to practice, and contact with patients.

Career choices are also influenced by family factors such as parents working in the health sector and the amount of parental income (Syakurah, 2014). Advice from family, friends, professors or even doctors also contributes to influencing career choices made (Al-Fouzan, 2012). In addition to personal interest in particular specialists (Huda, 2007) the desire to help the community is also a determining factor (Alawad, 2014).

Career choices made by medical students change over time between first year students and final year students. Students at the clinic stage tend to be more confident in choosing a career than students who are still in the stage of pre-clinic (Al-Fouzan, 2012). Career options between students in medical faculty who are one with other medical faculties may also be 
different. This cannot be separated from the input and process conditions and even the output of the medical faculty (Cleland, 2014). Good experience in pre-clinical stages such as in laboratory and clinical stages such as experience communicating with patients and clinical setting is one of the contributing factors (Saigal, 2007 and Boyle, 2014).

The role of the lecturer as a role model has an important role in providing an overview of specialization options by students. How to teach, appearance, how to communicate, attitudes and behavior, skills shown by the lecturer can encourage students to choose a career in accordance with the specialization of the lecturer. And vice versa, negative role model will make the students to not choose the specialization according to the specialization of the lecturer (Maulidira, 2015).

\section{Conclusion}

Conclusion of this research was no difference career preferences between preclinical and graduated students although graduated students has trough clinical education. Further research needed to identify factors influenced their career preferences.

\section{References}

Alawad AAMA, Khan WS, Abdelrazig YM, Elzain YI, Khalil HO, Ahmed OBE, Adam OAI, 2015. Factors considered by undergraduate medical students when selecting specialty of their future careers. Pan African Medical Journal. 20 (102):16.

Al-Fouzan R, Al-Ajlan S, Marwan Y, Al-Saleh M, 2012. Factors affecting future specialty choice among medical students in Kuwait. Med Educ Online. 17.19587.
Boyle V, Shulruf B, Poole P, 2014. Influence of gender and other factors on medical student specialty interest. The New Zealand Medical Journal. 127 (1402):7887.

Brodjonegoro SS, 2016. Kendalikan jumlah fakultas kedokteran. [www.kopertis12.or.id/2016/04/28/kendal ikan-jumlah-fakultas-kedokteran.html] Diakses tanggal 28 April 2016.

Cleland JA, Johnston PW, Anthony M, Khan N, Scott NW, 2014. A survey of factor influencing career preferences in new entrant and exiting medical students from four UK medical schools. BMC Medical Education. 14:151.

Ferdian D, Gondodiputro S, Dewi SP, 2015. Gambaran rencana masa depan pemilihan bidang profesi mahasiswa Fakultas Kedokteran Universitas Padjajaran angkatan 2007. 1 (1):35-42.

Fukuda Y, Harada T, 2010. Gender differences in specialty preference and mismatch with real needs in Japanese medical students. BMC Medical Education. 10:15.

Gondodiputro S, Djuhaeni H, Wiwaha G, 2009. Ekspektasi rencana masa depan mahasiswa program pendidikan kepaniteraan dokter (P3D) tahap dua Fakultas Kedokteran Universitas Padjajaran angkatan 2000-2001. Majalah Kedokteran Bandung. 41 (1): 18.

Hayes BW, Shakya R, 2013. Career choice and what influences Nepali medical students and young doctors: a cross-sectional study. Human Research for Health. 11:5.

Huda N, Yousuf S, 2006. Career preferences of final year medical students of Ziauddin 
Medical University. Education for Health. 19 (3): 345-353.

Ikatan Dokter Indonesia (IDI), 2016. Daftar Perhimpunan.

[http://www.idionline.org/about/perhimpu nan/] Diakses tanggal 25 April 2016.

Kemenkes RI, 2015. Profil Kesehatan Indonesia 2014. Kementerian Kesehatan RI.

Khader Y, Al-Zoubi D, Amarin Z, Alkafagei A, Khasawneh M, Burgan S, El Salem K, Omari M, 2008. BMC Medical Education. 8:32.

Lefevre $\mathrm{JH}$, Roupret $\mathrm{M}$, Kerneis $\mathrm{S}$, Karila L, 2010. Career choice of medical students: a national survey of 1780 students. Medical Education. 44:603-612.

Maulidira F, Syakurah RA, Fadilah M, Aulia H, 2015. Pengaruh role model terhadap pilihan karir pada mahasiswa fakultas kedokteran. Jurnal Pendidikan Kedokteran Indonesia. 4(2):75-82.

Mwachaka PM, Mbugua ET, 2010. Specialty references among medical students in a
Kenyan university. Pan African Medical Journal. 5:18.

Newton DA, Grayson MS, \& Thompson LF, 2005. The variable influence of lifestyle and income on medical students' career specialty choices: data from two US medical schools $1998-2004$. Academic Medicine. 80: 809 - 814

Saigal P, Takemura Y, Nishiue T, Fetters MD, 2007. Factors considered by medical students when formulating their specialty preferences in Japan: findings from a qualitative study. BMC Medical Education. 7:31.

She LB, Wu BL, Xu LY, Wu JY, Zhang PX, Li EM, 2008. Determinants of career aspirations of medical students in southern China. BMC Medical Education. 8:59.

Syakurah RA, Sari DA, Riansyah D, Yolanda P, 2014. Determinan pilihan karir mahasiswa fakultas kedokteran sebagai spesialis di Indonesia. Jurnal Pendidikan Kedokteran Indonesia. 3(2):132-136. 